\title{
Nicolau Syndrome After Glatiramer Acetate Injection in Close Proximity to Administration of SARS-CoV-2 mRNA Vaccine
}

\author{
Michael Yu Sy, MD, PhD, Erin Fromm, RN, Linda Doan, MD, PhD, Nathan Rojek, MD, and \\ Alexander Ulrich Brandt, MD
}

Neurol Neuroimmunol Neuroinflamm 2022;9:e1112. doi:10.1212/NXI.0000000000001112

\author{
Correspondence \\ Dr. Sy \\ msy@hs.uci.edu
}

Nicolau syndrome (synonym: embolia cutis medicamentosa) is a rare complication of subcutaneous and IM drug injections, typically independent of the drug itself. ${ }^{1}$ Patients develop painful purpuric and necrotizing lesions at the injection site, often requiring surgical intervention. The pathogenesis of the ischemic skin necrosis is poorly understood. We report 2 cases of skin necrosis associated with injection of glatiramer acetate (GA) in patients with multiple sclerosis (MS), which occurred in close temporal relation to the second dose of a severe acute respiratory syndrome coronavirus 2 (SARS-CoV2) mRNA vaccine.

\section{Case 1}

A 62-year-old man with a history of hyperlipidemia, obesity (body mass index of $30.1 \mathrm{~kg} / \mathrm{m}^{2}$ ), and MS received the first dose of the BNT162b2 vaccine in late March 2021. ${ }^{2}$ The patient had been stable on GA $40 \mathrm{mg}$ three times a week (Glatopa) for the past 5 years without new MRI lesions or relapses and no serious injection reactions. An injection of GA given in the lateral abdomen 17 days after the first vaccine dose resulted in retiform purpura surrounding the injection site (Figure, A). The purpura appeared 1 day before the second dose of the BNT162b2 vaccine and subsequently continued to spread (Figure, B). The injection site developed a necrotic black eschar (Figure, C). A punch biopsy obtained 14 days after vaccine dose 2 contained fibrin thrombi in the superficial and deep dermis, along with tissue necrosis indicative of thrombotic vasculopathy (Figure, D). Continued administration of GA after appearance of purpura did not lead to any further injection site reactions.

\section{Case 2}

A 59-year-old woman with a history of hypertension and MS received the first dose of the mRNA-1273 vaccine in early March 2021. ${ }^{3}$ The patient had been stable on GA $40 \mathrm{mg}$ three times a week (Copaxone) for more than 10 years without new MRI lesions or relapses. One week after the first vaccine dose, a large welt developed at the site of a GA injection near her right hip. Over the next few weeks, retiform purpura developed around the injection site. A central necrotic eschar developed when she received the second dose of the mRNA-1273 vaccine 4 weeks later, which enlarged over the next 7 days (Figure, E and F). She developed severe burning pain at the site of the wound, and the wound was debrided. Her local dermatologist diagnosed her with Nicolau syndrome but did not perform a biopsy. GA injections continued at other sites throughout the development of this purpuric skin lesion without further reactions. Roughly 10 years ago, she had experienced 1 skin reaction after GA injection that did not develop into the large ischemic lesion observed in the current case.

From the Department of Neurology (M.Y.S., E.F., U.B), Department of Pathology (L.D.), and Department of Dermatology (N.R.), University of California, Irvine. 
Figure Development of Retiform Purpura With Central Necrosis After Injection of Glatiramer Acetate (GA) in Close Association With Administration of BNT162b2 (A-D) and mRNA-1273 Vaccine (E and F)
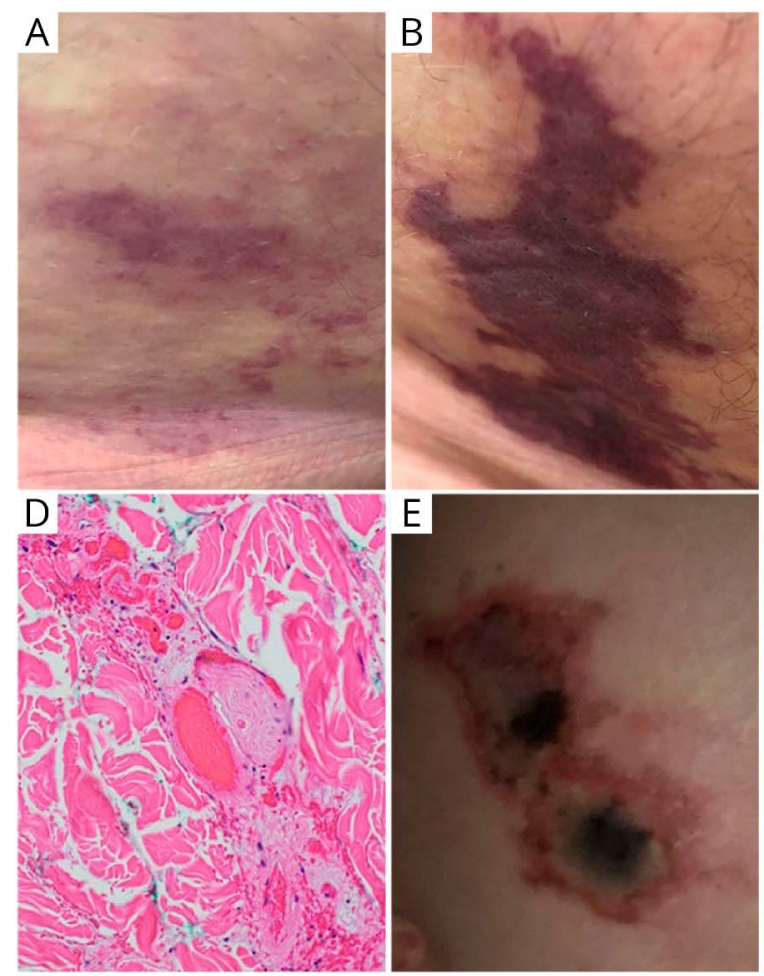
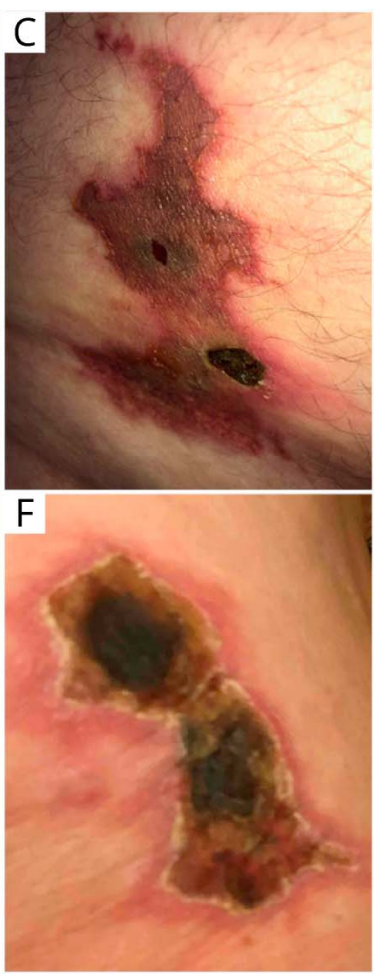

(A-C) Days 2 (A), 5 (B), and 14 (C) after injection of $\mathrm{GA}$ in close association with the BNT162b2 vaccine. (D) Representative micrograph of punch biopsy of cutaneous lesion revealing intravascular fibrin thrombi at day $14(\times 200)$. (E and F) Four weeks (E) and 5 weeks (F) after GA injection in close association with the mRNA-1273 vaccine.

\section{Discussion}

The COVID-19 pandemic has placed enormous health and economic burden on the worldwide community. The mRNA vaccines from Pfizer (BNT162b2) and Moderna (mRNA1273) are notable achievements, highly effective in preventing severe COVID-19 syndromes. ${ }^{2,3}$ Our second patient reported typical side effects including fever, fatigue, headache, chills, and muscle pain, whereas the first patient had no side effects. Complications related to drug interactions in specific populations have not been reported.

Nicolau syndrome is an exceedingly rare, adverse event in GAtreated patients with MS. ${ }^{1,4}$ Occurrence of Nicolau syndrome in 2 patients with MS at our MS center in close proximity to SARS-CoV2 vaccination with mRNA vaccines raises the possibility of an association between the 2 . No other reports of similar skin lesions were observed in our vaccine program at UC Irvine. Our MS center currently has 224 patients on GA, with an estimated $70 \%-80 \%$ having received a SARS-CoV2 vaccine. Of interest, the joint targets of both interventions are professional antigen-presenting dendritic cells (DCs): mRNA vaccines work via mRNA delivery to DCs at the injection site, which then produce and present mRNA-encoded viral antigen to initiate an immune response. ${ }^{5}$ Although the mechanisms of GA on the immune system are broad, DCs act as the initial target for drug uptake and presentation. ${ }^{6}$ Both patients have been stable on GA, and both tested positive for antibodies against SARS-CoV2 4 months after vaccination.

We report these cases to make MS centers aware of this potential complication. Although our 2 observations are by no means a proof of causation, they suggest that providers and patients should carefully monitor GA injections in close proximity to SARS-CoV2 vaccinations with $\mathrm{mRNA}$ vaccine. A timely response coordinated with dermatology has been reported to prevent necrosis and scar formation, but it is unclear whether this approach may also be successful under these new circumstances. ${ }^{7}$ Of note, our observation may also be of relevance for other injectables, as Nicolau syndrome has also been observed with other substances, and may be attributed to mechanical affection of the tissue rather than to drug-related effects.

\section{Study Funding}

No targeted funding reported.

\section{Disclosure}

The authors report no disclosures relevant to the manuscript. Go to Neurology.org/NN for full disclosures.

\section{Publication History}

Received by Neurology: Neuroimmunology \& Neuroinflammation April 30, 2021. Accepted in final form August 30, 2021. 
Appendix Authors

\begin{tabular}{lll}
\hline Name & Location & Contribution \\
\hline $\begin{array}{l}\text { Michael Yu } \\
\text { Sy, MD, PhD }\end{array}$ & $\begin{array}{l}\text { Department of } \\
\text { Neurology, University of } \\
\text { California, Irvine }\end{array}$ & $\begin{array}{l}\text { Drafting/revision of the } \\
\text { manuscript for content, } \\
\text { including medical writing for } \\
\text { content; major role in the } \\
\text { acquisition of data; study } \\
\text { concept or design; and } \\
\text { analysis or interpretation of } \\
\text { data }\end{array}$ \\
\hline $\begin{array}{l}\text { Erin Fromm, } \\
\text { RN }\end{array}$ & $\begin{array}{l}\text { Department of } \\
\text { California, Irvine }\end{array}$ & $\begin{array}{l}\text { Major role in the acquisition of } \\
\text { data and study concept or } \\
\text { design }\end{array}$ \\
\hline $\begin{array}{l}\text { Linda Doan, } \\
\text { MD, PhD }\end{array}$ & $\begin{array}{l}\text { Department of Pathology, } \\
\text { University of California, } \\
\text { Irvine }\end{array}$ & $\begin{array}{l}\text { Drafting/revision of the } \\
\text { manuscript for content, } \\
\text { including medical writing for } \\
\text { content, and major role in the } \\
\text { acquisition of data }\end{array}$ \\
\hline $\begin{array}{l}\text { Nathan } \\
\text { Rojek, MD }\end{array}$ & $\begin{array}{l}\text { Department of } \\
\text { Dermatology, University } \\
\text { of California, Irvine }\end{array}$ & $\begin{array}{l}\text { Drafting/revision of the } \\
\text { manuscript for content, } \\
\text { including medical writing for } \\
\text { content, and major role in the } \\
\text { acquisition of data }\end{array}$ \\
& &
\end{tabular}

Appendix (continued)

\begin{tabular}{lll}
\hline Name & Location & Contribution \\
\hline $\begin{array}{l}\text { Alexander } \\
\text { Ulrich } \\
\text { Brandt, MD }\end{array}$ & $\begin{array}{l}\text { Department of } \\
\text { Neurology, University of } \\
\text { California, Irvine }\end{array}$ & $\begin{array}{l}\text { Drafting/revision of the } \\
\text { manuscript for content, } \\
\text { including medical writing for } \\
\text { content; major role in the } \\
\text { acquisition of data; study } \\
\text { concept or design; and analysis } \\
\text { or interpretation of data }\end{array}$ \\
& & \\
&
\end{tabular}

\section{References}

1. Kimbrough DJ, Newsome SD. Case report: two cases of Nicolau syndrome associated with glatiramer acetate. Int J MS Care. 2017;19(3):148-150.

2. Polack FP, Thomas SJ, Kitchin N, et al. Safety and efficacy of the BNT162b2 mRNA Covid-19 vaccine. $N$ Engl J Med. 2020;383(3):2603-2615.

3. Baden LR, Sahly HME, Essink B, et al. Efficacy and safety of the mRNA-1273 SARSCoV-2 vaccine. N Engl J Med. 2021;384(3):403-416.

4. Bosca I, Bosca M, Belengeur A, et al. Necrotising cutaneous lesions as a side effect of glatiramer acetate. J Neurol. 2006;253(3):1370-1371.

5. Pardi N, Hogan MJ, Porter FW, Weissman D. mRNA vaccines-a new era in vaccinology. Nat Rev Drug Discov. 2018;17(3):261-279.

6. Prod'homme T, Zamvil SS. The evolving mechanisms of action of glatiramer acetate. Cold Spring Harb Perspect Med. 2019;9(3):a029249.

7. Geukens J, Rabe E, Bieber T. Embolias cutis medicamentosa of the foot after sclerotherapy. Eur J Dermatol. 1999;9(3):132-133. 


\title{
Neurology $^{\odot}$ \\ Neuroimmunology \& Neuroinflammation
}

\author{
Nicolau Syndrome After Glatiramer Acetate Injection in Close Proximity to \\ Administration of SARS-CoV-2 mRNA Vaccine \\ Michael Yu Sy, Erin Fromm, Linda Doan, et al. \\ Neurol Neuroimmunol Neuroinflamm 2022;9; \\ DOI 10.1212/NXI.0000000000001112
}

This information is current as of November 10, 2021

\section{Updated Information \& \\ Services}

References

Subspecialty Collections

Permissions \& Licensing

Reprints including high resolution figures, can be found at:

http://nn.neurology.org/content/9/1/e1112.full.html

This article cites 7 articles, 1 of which you can access for free at: http://nn.neurology.org/content/9/1/e1112.full.html\#\#ref-list-1

This article, along with others on similar topics, appears in the following collection(s):

COVID-19

http://nn.neurology.org//cgi/collection/covid_19

Multiple sclerosis

http://nn.neurology.org//cgi/collection/multiple_sclerosis

Information about reproducing this article in parts (figures,tables) or in its entirety can be found online at:

http://nn.neurology.org/misc/about.xhtml\#permissions

Information about ordering reprints can be found online:

http://nn.neurology.org/misc/addir.xhtml\#reprintsus

Neurol Neuroimmunol Neuroinflamm is an official journal of the American Academy of Neurology.

Published since April 2014, it is an open-access, online-only, continuous publication journal. Copyright

Copyright (C) 2021 The Author(s). Published by Wolters Kluwer Health, Inc. on behalf of the American

Academy of Neurology.. All rights reserved. Online ISSN: 2332-7812.

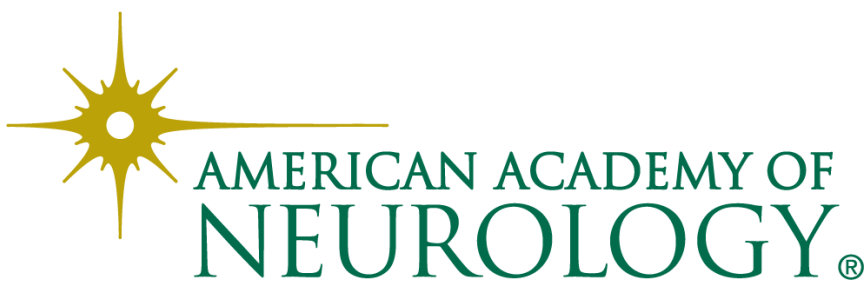

